\title{
Effect of Sequential Cold Shocks on Survival and Molting Rate in Triatoma infestans Klug
}

\author{
Silvana GP Campos, Vera Lúcia CC Rodrigues**, CY Wada*, Maria Luiza S Mello/ ${ }^{+}$
}

\author{
Departamento de Biologia Celular, Instituto de Biologia *Departamento de Estatística, Instituto de Matemática, Estatística e \\ Computação Científica, Universidade Estadual de Campinas (Unicamp), 13084-971 Campinas, SP, Brasil \\ **Sucen, Mogi-Guaçu, SP, Brasil
}

\begin{abstract}
The survival and molting incidence in Triatoma infestans, a vector of Chagas disease, were investigated following sequential shocks at $0^{\circ} \mathrm{C}$ in fifth instar nymphs under moderate fasting and full nutritional conditions. The shocks were separated by intervals of $8 \mathrm{~h}$ and $24 \mathrm{~h}$ at $30^{\circ} \mathrm{C}$. The results indicated that in terms of insect survival, $\mathrm{T}$. infestans is tolerant to a single cold shock at $0^{\circ} \mathrm{C}$ even for $12 \mathrm{~h}$, or to sequential cold shocks, regardless of the nutritional state of the specimens. In terms of molting rate, fasting enhanced the tolerance to sequential cold shocks, but did not exceed the tolerance acquired by fully-nourished specimens, except when cold shocks were separated by an $8 \mathrm{~h}$ interval at $30^{\circ} \mathrm{C}$. The protective action elicited by fasting was assumed to be additive to that induced by a single mild cold shock or sequential cold shocks. The cold-tolerance response of $\mathrm{T}$. infestans may have favoured its survival in areas of South America with low temperatures, even considering that this species is predominantly associated with human habitats.
\end{abstract}

Key words: Triatoma infestans - nutritional conditions - cold-shock tolerance - survival - molting rate

The survival, molting incidence and chromatin supraorganization of Triatoma infestans and Panstrongylus megistus, blood-sucking hemipteran vectors of Chagas disease, are affected by stressing agents, including heat and cold shocks (Rodrigues et al. 1991, Dantas \& Mello 1992, Mello et al. 1995, Garcia et al. 1999, 2000). These insect species differ in nuclear characteristics (Mello 1971, 1975, Mello et al. 1986) and in their response to heat and cold shocks (Rodrigues et al. 1991, Garcia et al. 1999), with $P$. megistus being less resistant to prolonged heat $\left(40^{\circ} \mathrm{C}\right)$ and cold $\left(0^{\circ} \mathrm{C}\right)$ shocks than T. infestans (Rodrigues et al. 1991, Garcia et al. 1999).

Thermotolerance following sequential heat shocks and tolerance to sequential cold shocks (i.e., an acquired increase in survival and molting incidence) have been reported in P. megistus (Garcia et al. 2001a,b). Cold-shock tolerance in insects has been suggested to involve the synthesis of heat-shock or other proteins, as well as the presence of cryoprotectants and improved use of metabolic energy resources (Clark \& Fucito 1998). There is no evidence of cryoprotectant use in blood-sucking hemipterans. However, the synthesis of heat-shock proteins during the cold-shock tolerance response has been suggested for P. megistus (Garcia et al. 2001a).

This paper received financial support from Fapesp (grant no. 99/2547-8), Capes and CNPq. This study was part of a thesis presented by SGPC to the Instituto de Biologia, Unicamp, in partial fullfilment of the requirements for a Master degree.

${ }^{+}$Corresponding author. Fax: +55-19-3289.3124. E-mail: mlsmello@unicamp.br

Received 28 August 2001

Accepted 12 December 2001
Since no generalization can be made about the responses of different species of the same family to temperature shocks (Clark \& Fucito 1998), and since $T$. infestans and P. megistus differ from each other in several aspects, including their responses to heat and cold shocks, it is possible that $T$. infestans may respond differently to sequential cold shocks compared to P. megistus. This response may be affected by the state of nourishment of the insects (Garcia et al. 1999).

In the present study, survival and molting incidence were investigated in T. infestans after sequential cold shocks under different conditions of nourishment and the responses compared to those of P. megistus (Garcia et al. 2001a).

\section{MATERIALS AND METHODS}

Fifth instar nymphs of $T$. infestans Klug (Hemiptera, Reduviidae) reared at $30^{\circ} \mathrm{C}$ and $80 \%$ relative humidity in the laboratory at Sucen (Mogi-Guaçu, SP) were used. The insects fed once a week on hen blood. Some specimens were fasted for up to 15 days before and up to 30 days after the shocks.

Immediately after a shock at $0^{\circ} \mathrm{C}$ for $1 \mathrm{~h}$, the nymphs were returned to control conditions and $8 \mathrm{~h}$ and $24 \mathrm{~h}$ later were subjected to a second shock at $0^{\circ} \mathrm{C}$ which lasted 12 h. The temperature of $0^{\circ} \mathrm{C}$ was chosen based on a previous report (Rodrigues et al. 1991).

Nymphs maintained at $30^{\circ} \mathrm{C}$, a temperature traditionally used for rearing $T$. infestans in the insect facilities at Sucen since 1980 (Rodrigues et al. 1991)(control \#1), as well as nymphs subjected to a single shock at $0^{\circ} \mathrm{C}$ for $1 \mathrm{~h}$ (control \#2) and $12 \mathrm{~h}$ (control \#3) were used as controls.

After the shocks, the nymphs were returned to the control temperature $\left(30^{\circ} \mathrm{C}\right)$ and monitored daily for 32 days to score the survival rate and molting incidence.

The molting rates and curves were compared statistically using a non-parametric log-rank test (Collet 1994). 
The log-rank test used was considered efficient for comparisons when the functions expressing the absence of molting in the various groups were proportional, and their resulting curves did not cross. When the resulting curves crossed, the $\chi^{2}$ test was used to compare the presence and absence of molting.

\section{RESULTS}

The survival rate of the nymphs subjected to a single short (1 h, control \#2) or long (12 h, control \#3) shock at $0^{\circ} \mathrm{C}$ or to sequential shocks at $0^{\circ} \mathrm{C}$ interspersed by an 8 or 24-h period at $30^{\circ} \mathrm{C}$ did not differ from each other or from that of the non-shocked nymphs (control \#1), regardless of the nutritional condition of the specimens (Table I).

Similarly, the molting rate of fully-nourished insects subjected to a single short or long shock did not differ from each other or from that of the non-shocked insects. There was no significant difference in the molting rate of fully-nourished nymphs after sequential shocks compared to that after a single shock (Table II). Although there was an apparent increase in the molting incidence 32 days after sequential shocks when the period between shocks was $24 \mathrm{~h}$ (Table I), and the resulting p-value for the log- rank test was significant for the comparison of this condition with control \#3 (Table II), the resulting curves for the lack of molting in these groups crossed (data not shown), and the $\mathrm{p}$-value for the $\chi^{2}$ test was not significant (Table II).

In all cases, the molting started earlier in the fasted specimens, which also showed a larger variability in the time of molting when compared with fully-nourished specimens (Table III).

Fasting increased significantly the incidence and rate of molting after a single short cold shock, but decreased these parameters after a single long cold shock, when compared with the state of full nourishment (Tables I, IV). A cold-shock tolerance response induced in the fasted specimens by sequential cold-shock treatment was detected as an increase in the molting rate values compared with those after a single long shock (Tables I, II). However, values comparable to those obtained after the single one-hour shock were not attained (Tables I, II). The molting rates attained after the sequential shocks were the same in the fasted specimens, regardless of the time between shocks (Tables II, IV). The molting rate after a $24 \mathrm{~h}$ period between shocks did not vary with the nutritional condition of the nymphs (Table IV).

TABLE I

Survival and molting incidence (\%) in fifth instar nymphs of Triatoma infestans (n: 50) 32 days after sequential cold shocks

\begin{tabular}{|c|c|c|c|c|}
\hline \multirow[t]{2}{*}{ Experimental condition } & \multicolumn{2}{|c|}{ Survival (\%) } & \multicolumn{2}{|c|}{ Molting incidence $(\%)^{a}$} \\
\hline & $\mathrm{N}$ & $\mathrm{F}$ & $\mathrm{N}$ & $\mathrm{F}$ \\
\hline Control \#1, 30 ${ }^{\circ} \mathrm{C}$ & 96 & 100 & 80 & \\
\hline Control $\# 2$, a single shock at $0^{\circ} \mathrm{C}(1 \mathrm{~h})$ & 98 & 100 & 72 & 98 \\
\hline Control \#3, a single shock at $0^{\circ} \mathrm{C}(12 \mathrm{~h})$ & 100 & 98 & 76 & 52 \\
\hline \multicolumn{5}{|l|}{ Time (h) at $30^{\circ} \mathrm{C}$ between shocks } \\
\hline 8 & 100 & 100 & 66 & 82 \\
\hline 24 & 96 & 100 & 88 & 86 \\
\hline
\end{tabular}

F: fasted nymphs; $\mathrm{N}$ : fully-nourished specimens; $a: \chi^{2}=39.82 ;$ d.f. $=7$ (control \#1 not included; $\left.\mathrm{p}=0.001\right)$

TABLE II

Comparison of the molting rates of cold-shocked nymphs of Triatoma infestans

\begin{tabular}{|c|c|c|c|c|c|c|c|c|}
\hline \multirow[t]{3}{*}{ Nutrition } & \multicolumn{4}{|c|}{ Conditions compared } & \multicolumn{2}{|c|}{ Log-rank test } & \multicolumn{2}{|c|}{$\chi^{2}$ test } \\
\hline & \multicolumn{2}{|c|}{ Control $\left(0^{\circ} \mathrm{C}, \mathrm{h}\right)$} & \multicolumn{2}{|c|}{$\begin{array}{l}\text { Intervals at } 30^{\circ} \mathrm{C} \\
\text { between shocks }(\mathrm{h})\end{array}$} & \multirow[t]{2}{*}{$\begin{array}{l}\text { Log-rank } \\
\text { value }\end{array}$} & \multirow[t]{2}{*}{ p-value } & \multirow[t]{2}{*}{$\chi^{2}$ value } & \multirow[t]{2}{*}{ p-value } \\
\hline & 1 & 12 & 8 & 24 & & & & \\
\hline \multirow[t]{5}{*}{ Full } & $\mathrm{X}$ & $X$ & & & 0.16 & 0.68 & 0.20 & 0.65 \\
\hline & $\mathrm{X}$ & & $\mathrm{X}$ & & 1.34 & 0.25 & 0.42 & 0.52 \\
\hline & $\mathrm{X}$ & & & $X$ & 2.53 & 0.11 & 2.95 & 0.08 \\
\hline & & $X$ & $\mathrm{X}$ & & 0.72 & 0.40 & 1.21 & 0.27 \\
\hline & & $X$ & & $X$ & 5.23 & $0.02^{a}$ & 1.62 & 0.20 \\
\hline \multirow[t]{6}{*}{ Fasting } & $\mathrm{X}$ & $\mathrm{X}$ & & & 29.69 & $<0.01^{b}$ & 28.21 & $<0.01^{b}$ \\
\hline & $\mathrm{X}$ & & $\mathrm{X}$ & & 6.21 & $0.01^{b}$ & 7.11 & $<0.01^{b}$ \\
\hline & $X$ & & & $X$ & 5.18 & $0.02^{a}$ & 4.89 & $0.02^{a}$ \\
\hline & & $X$ & $\mathrm{X}$ & & 9.46 & $<0.01^{b}$ & 10.17 & $<0.01^{b}$ \\
\hline & & $X$ & & $X$ & 11.36 & $<0.01$ & 13.51 & $<0.01^{b}$ \\
\hline & & & $\mathrm{X}$ & $\mathrm{X}$ & 0.14 & 0.71 & 0.29 & 0.58 \\
\hline
\end{tabular}

$a$ : significant; $b$ : highly significant 
TABLE III

Summary statistics regarding molting incidence along a 32-day period after sequential cold shocks

\begin{tabular}{|c|c|c|c|c|c|c|}
\hline \multirow[t]{2}{*}{ Treatments } & \multirow[t]{2}{*}{ Nutritional state } & \multicolumn{5}{|c|}{ Molting incidence time (days) } \\
\hline & & Average & Standard error & Minimal & Median & Maximal \\
\hline Control \#2 & $\mathrm{N}$ & 24.8 & 0.7 & 15. & 26. & 31. \\
\hline Control \#3 & $\mathrm{N}$ & 26.1 & 0.6 & 18. & 26. & 31. \\
\hline \multicolumn{7}{|c|}{ Time (h) at $30^{\circ} \mathrm{C}$ between shocks } \\
\hline 8 & $\mathrm{~N}$ & 26.3 & 0.6 & 16. & 28. & 31. \\
\hline 24 & $\mathrm{~N}$ & 23.6 & 0.7 & 15. & 22. & 31. \\
\hline Control \#2 & $\mathrm{F}$ & 17.4 & 0.9 & 4. & 17.5 & 32. \\
\hline Control \#3 & $\mathrm{F}$ & 23.1 & 0.9 & 4. & 28. & 29. \\
\hline \multicolumn{7}{|c|}{ Time (h) at $30^{\circ} \mathrm{C}$ between shocks } \\
\hline 8 & $\mathrm{~F}$ & 20.1 & 1.1 & 4. & 20. & 32. \\
\hline 24 & $\mathrm{~F}$ & 20.2 & 1. & 7. & 19. & 32. \\
\hline
\end{tabular}

F: fasting; $\mathrm{N}$ : fully nourishment; \#2: a single shock at $0^{\circ} \mathrm{C}(1 \mathrm{~h})$; \#3: a single shock at $40^{\circ} \mathrm{C}(12 \mathrm{~h})$

TABLE IV

Effect of the nutritional state of Triatoma infestans nymphs on the cold-shock response expressed as molting rate

\begin{tabular}{|c|c|c|c|c|}
\hline \multirow{2}{*}{$\begin{array}{l}\text { Items compared under full nourishment } \\
\text { vs fasting conditions }\end{array}$} & \multicolumn{2}{|c|}{ Log-rank test } & \multicolumn{2}{|c|}{$\chi^{2}$ test $^{b}$} \\
\hline & Log-rank value & p-value & $\chi^{2}$ value & p-value \\
\hline Control, a single shock at $0^{\circ} \mathrm{C}(1 \mathrm{~h})$ & 33.29 & $0.0001^{a}$ & & \\
\hline Control, a single shock at $0^{\circ} \mathrm{C}(12 \mathrm{~h})$ & 0.31 & 0.5800 & 6.25 & $0.0124^{a}$ \\
\hline \multicolumn{5}{|l|}{ Time (h) at $30^{\circ} \mathrm{C}$ between shocks } \\
\hline 8 & 13.78 & $0.0002^{a}$ & & \\
\hline 24 & 3.65 & 0.0558 & & \\
\hline
\end{tabular}

$a$ : highly significant; $b$ : values nominated only when more efficient than the log-rank values since the resulting curves for absence of molting crossed

\section{DISCUSSION}

T. infestans was tolerant to cold shock at $0^{\circ} \mathrm{C}$ for up to $12 \mathrm{~h}$. This response was not affected by sequential cold shocks or the nutritional state of the specimens, and differed from that of $P$. megistus, a blood-sucking hemipteran of the same family as $T$. infestans and with a wide geographical distribution in Brazil (Forattini 1980). Less than $10 \%$ of fifth instar $P$. megistus nymphs survive 30 days after a single $12 \mathrm{~h}$ shock at $0^{\circ} \mathrm{C}$, although cold tolerance is acquired when the specimens are subjected to sequential cold shocks (Garcia et al. 2001a). The cold-hardening response of $T$. infestans may have facilitated the successful survival of this species at altitudes up to $7,000 \mathrm{~m}$ in the Andes mountains (Usinger et al. 1966) and its spread throughout regions of South America with seasonally low temperatures, besides adaptation to Neotropical areas of this continent, particularly in association with human movements and habitats.

Although survival was not affected by the cold-shock treatments, molting occurred earlier in moderately fasted fifth instar nymphs exposed to single or sequential cold shocks and varied with time when compared to fully-nourished specimens. Fasting enhanced the tolerance to sequential cold shocks (reflected in the molting rates) but not beyond that acquired by fully-nourished specimens, except when the period at $30^{\circ} \mathrm{C}$ between cold shocks was short $(8 \mathrm{~h})$. A specific time at $30^{\circ} \mathrm{C}$, between cold shocks, was not found to induce enhancement in molting rate com- pared to the rate obtained after the single cold shock for $12 \mathrm{~h}$ in fully-nourished nymphs. In fasted specimens, the $8 \mathrm{~h}$ and $24 \mathrm{~h}$ intervals allowed the insects to supercede the tolerance level obtained with a single drastic cold shock, in a manner similar to fasted $P$. megistus nymphs (Garcia et al. 2001a). However, the change in molting rate caused by sequential cold shocks in $P$. megistus was much less marked than in T. infestans (Garcia et al. 2001a). Since fasting is also a stress factor, the cell protection it induces may be additive to that elicited by sequential cold shocks or a single mild cold shock.

Hsp and other protective mechanisms may operate concurrently to induce the cold-hardening response in $P$. megistus (Garcia et al. 2001a). These mediators may also be responsible for the cold-shock hardening response in T. infestans, in which the ability to survive low temperatures is more developed and probably was more efficiently selected for (Chen \& Walker 1993). The divergent responses to sequential cold shocks in T. infestans and $P$. megistus also agree with the idea that genotypes may respond differently to environmental stress by varying their regulation of energy metabolism. This variation in the response to stress may be important in maintaining genetic variation in metabolic traits (Clark \& Fucito 1998).

\section{REFERENCES}

Chen CP, Walker VK 1993. Increase in cold-shock tolerance by selection of cold resistant lines in Drosophila melanogaster. Ecol Entomol 18: 184-190. 
Clark AG, Fucito CD 1998. Stress tolerance and metabolic response to stress in Drosophila melanogaster. Heredity 81: 514-527.

Collet D 1994. Modelling Survival Data in Medical Research, Chapman \& Hall, London.

Dantas MM, Mello MLS 1992. Changes in the nuclear phenotypes of Triatoma infestans Klug, induced by thermal shocks. Rev Bras Genét 15: 509-519.

Forattini OP 1980. Biogeografia, origem e distribuição da domiciliação de triatomíneos no Brasil. Rev Saúde Públ 14: 265-299.

Garcia SL, Garcia NL, Rodrigues VLCC, Mello MLS 2001a. Effect of sequential cold shocks on survival and molting incidence in Panstrongylus megistus (Burmeister) (Hemiptera, Reduviidae). Cryobiology 42: 74-77.

Garcia SL, Mello MLS, Garcia NL, Rodrigues VLCC 2001b. Experimentally induced heat-shock tolerance in Panstrongylus megistus (Burmeister) (Hemiptera, Reduviidae). J Med Entom 38: 510-513.

Garcia SL, Mello MLS, Rodrigues VLCC, Garcia NL 2000. Nuclear phenotype changes after heat shock in Panstrongylus megistus (Burmeister). Mem Inst Oswaldo Cruz. 95: 271-277.

Garcia SL, Rodrigues VLCC, Garcia NL, Ferraz Filho AN, Mello
MLS 1999. Survival and molting incidence after heat and cold shocks in Panstrongylus megistus Burmeister. Mem Inst Oswaldo Cruz 94: 131-137.

Mello MLS 1971. Nuclear behaviour in the Malpighian tubes of Triatoma infestans (Reduv., Hemiptera). Cytologia 36: 42-49.

Mello MLS 1975. Feulgen-DNA values and ploidy degrees in the Malpighian tubes of some triatomids. Rev Brasil Pesq Méd Biol 8: 101-107.

Mello MLS, Kubrusly FS, Randi MAF, Rodrigues VLCC, Ferraz Filho AN 1995. Effects of heavy metals on chromatin supraorganization, nuclear phenotypes, and survival of Triatoma infestans. Entomol Exp Appl 74: 209-218.

Mello MLS, Randi MAF, Giorgio S, Ferraz-Filho AN, Rodrigues VLCC, Rocha-e-Silva EO, Cordeiro JA 1986. Number of chromosomes, Feulgen-DNA content and nuclear phenotypes in domestic and wild specimens of Panstrongylus megistus. Ann Trop Med Parasitol 80: 641-648.

Rodrigues VLCC, Mello MLS, Ferraz Filho AN, Dantas MM 1991. Sobrevivência e ocorrência de muda em Triatoma infestans Klug (Hemiptera, Reduviidae) após choque de temperatura. Rev Saúde Públ 25: 461-467.

Usinger RL, Wygodzinsky P, Ryckman RE 1966. The biosystematics of Triatominae. Ann Rev Entomol 11: 309-330. 